\title{
Glycosylation and Secretion of Human Tissue Plasminogen Activator in Recombinant Baculovirus-Infected Insect Cells
}

\author{
DONALD L. JARVIS* AND MAX D. SUMMERS \\ Department of Entomology and Texas Agricultural Experiment Station, Texas A\&M University, \\ College Station, Texas 77843
}

Received 15 July 1988/Accepted 19 October 1988

\begin{abstract}
Cell lines established from the lepidopteran insect Spodoptera frugiperda (fall armyworm; Sf9) are used routinely as hosts for the expression of foreign proteins by recombinant baculovirus vectors. We have examined the pathway of protein glycosylation and secretion in these cells, using human tissue plasminogen activator (t-PA) as a model. t-PA expressed in Sf9 cells was both $\mathbf{N}$ glycosylated and secreted. At least a subset of the $\mathrm{N}$-linked oligosaccharides in extracellular t-PA was resistant to endo- $\boldsymbol{\beta}-\mathrm{N}$-acetyl-D-glucosaminidase $\mathrm{H}$, which removes immature, high-mannose-type oligosaccharides. This refutes the general conclusion from previous studies that Sf9 cells cannot process immature $\mathbf{N}$-linked oligosaccharides to an endo- $\boldsymbol{\beta}$ - $\boldsymbol{N}$-acetyl-D-glucosaminidase H-resistant form. A nonglycosylated t-PA precursor was not detected in Sf9 cells, even with very short pulse-labeling times. This suggests that the mammalian signal sequence of $t-P A$ is efficiently recognized in Sf9 cells and that it can mediate rapid translocation across the membrane of the rough endoplasmic reticulum, where cotranslational $\mathbf{N}$ glycosylation takes place. However, t-PA was secreted rather slowly, with a half-time of about $1.6 \mathrm{~h}$. Thus, a rate-limiting step(s) in secretion occurs subsequent to translocation and $\mathrm{N}$ glycosylation of the t-PA polypeptide. Treatment of Sf9 cells with tunicamycin, but not with inhibitors of oligosaccharide processing, prevented the appearance of $t-P A$ in the extracellular medium. This suggests that $\mathbf{N}$ glycosylation per se, but not processing of the $\mathrm{N}$-linked oligosaccharides, is required directly or indirectly in baculovirusinfected Sf9 cells for the secretion of t-PA. Finally, the relative efficiency of secretion decreased dramatically with time of infection, suggesting that the Sf9 host cell secretory pathway is compromised during the later stages of baculovirus infection.
\end{abstract}

The use of recombinant baculoviruses as expression vectors has intensified in recent years to the extent that more than 50 different genes have now been expressed in this system (reviewed in reference 19). In general, this approach involves the construction and isolation of recombinant baculoviruses in which the coding sequence for a chosen gene has been inserted behind the promoter for the nonessential viral gene, polyhedrin $(25,31,33)$. The overwhelming advantage of baculovirus vectors is that they express many foreign gene inserts at extraordinarily high levels, as a result of the relative strength of the polyhedrin promoter. However, the use of baculovirus vectors relies upon host cells derived from lepidopteran insects, and historically, this has contributed a measure of uncertainty to the system. Little is known about the molecular mechanisms of protein processing in these invertebrate cells, and most of the genes that have been inserted into the viral expression vector are derived from vertebrate species. Thus, it has been difficult to predict whether authentic and/or functional proteins could be produced with this system.

In several published studies of baculovirus-mediated gene expression, this problem has been addressed by analyses of the structures and/or functions of various foreign protein products synthesized in insect cells. The usual host cell is Sf9, a clonal isolate of the IPLB-Sf21-AE line established from Spodoptera frugiperda (fall armyworm), and the usual result is that the proteins are essentially authentic and are antigenically and/or biologically active (reviewed in reference 19). However, more detailed investigations have suggested that Sf9 cells and mammalian cells exhibit some differences in their basic mechanisms of protein glycosyl-

\footnotetext{
* Corresponding author.
}

ation $(10,17,28,44)$. Glycoproteins expressed in Sf9 cells clearly undergo the initial step of $\mathbf{N}$ glycosylation, defined in mammalian cells as the cotranslational addition of a highmannose oligosaccharide to the polypeptide chain (reviewed in reference 14). However, current data suggest that, unlike their mammalian counterparts, Sf 9 cells are incapable of processing the immature oligosaccharide to a complex form. So far, this conclusion has been based upon the finding that glycoproteins derived from $\mathrm{S} 9$ cells remain sensitive to endo- $\beta$ - $N$-acetyl-D-glucosaminidase $\mathrm{H}$ (endo- $\mathrm{H} ; 38$ ), an endoglycosidase capable of removing only high-mannose oligosaccharide side chains. Direct chemical analyses of N-linked oligosaccharides isolated from mammalian glycoproteins synthesized in Sf9 cells has not yet been reported.

Tissue plasminogen activator (t-PA) functions to convert the zymogen, plasminogen, to its enzymatically active form, plasmin, which then acts directly to cause the lysis of blood clots and the destruction of clotting factors. $t$-PA has direct therapeutic use in humans as a thrombolytic agent and appears to reduce mortality in heart attack victims (34). The human t-PA polypeptide has a calculated molecular mass of about 59,000 (59 kilodaltons [kDa]; 24) and contains a cleavable amino-terminal signal sequence for translocation across the membrane of the rough endoplasmic reticulum from amino acid 1 to amino acid 20, a prosequence from amino acid 20 or 23 to amino acid 35 , and four potential $\mathbf{N}$ glycosylation sites (24). Biochemical studies of t-PA purified from mammals have shown that it may occur in several forms $(26,27,29,42,43)$. The intact, or single-chain, t-PA polypeptide can undergo proteolysis to produce a two-chain form, consisting of disulfide-linked A (heavy) and B (light) chains. It has been shown that $\mathbf{N}$ glycosylation may occur at either two or three of the four potential recognition sites. All 
molecules appear to undergo glycosylation at one site in each of the A and B chains (variant II), while a subpopulation is glycosylated at an additional site in the $A$ chain (variant I). The $\mathrm{N}$-linked oligosaccharide on the $\mathrm{A}$ chain of mammalian variant II t-PA has a high-mannose structure, while that on the $B$ chain is of the complex type, as is the additional oligosaccharide on the $A$ chain of mammalian variant I t-PA. The reported apparent molecular mass values for single-chain t-PA range from 63 to $72 \mathrm{kDa}$, with a difference of about $3 \mathrm{kDa}$ between variants I and II. Upon reduction, the two-chain form of t-PA is converted to free $B$ chains of about $33 \mathrm{kDa}$ and $\mathrm{A}$ chains of about $37 \mathrm{kDa}$ (variant II) or $40 \mathrm{kDa}$ (variant I).

In this study, we have used human t-PA as a model to probe the pathway of $\mathrm{N}$ glycosylation and secretion in baculovirus-infected Sf9 cells. New information was obtained on several aspects of this pathway. Pulse-chase experiments indicated that the mammalian signal sequence of t-PA is recognized efficiently in Sf9 cells and that it can mediate rapid translocation across the membrane of the rough endoplasmic reticulum, where $\mathrm{N}$ glycosylation of the polypeptide takes place. A previously unrecognized degree of N-linked oligosaccharide processing was documented in Sf 9 cells, and a role for cellular glucosidase(s) in the Sf9 cell $\mathrm{N}$ glycosylation pathway was implicated. Finally, the relationship between $\mathrm{N}$ glycosylation and secretion of t-PA was investigated, as was the effect of virus infection on the secretion on the human t-PA from Sf9 cells. We speculate that the results described in this study reflect, in a more general sense, characteristics of the leptidopteran insect cell pathway which accomplish the $\mathrm{N}$ glycosylation and secretion of foreign or naturally occurring glycoproteins.

\section{MATERIALS AND METHODS}

Cells and viruses. The Sf9 clone of IPLB-Sf21-AE cells (41) was maintained as a monolayer culture in TN-MFH medium containing $10 \%$ heat-inactivated fetal bovine serum (Hazelton Research Products, Inc., Lenexa, Kans.) and subcultured every 3 days at $2.0 \times 10^{6}$ to $2.5 \times 10^{6}$ cells per flask (35). The E2 strain of wild-type Autographa californica nuclear polyhedrosis virus (AcMNPV; 32) and 373-t-PA, the recombinant baculovirus encoding human t-PA, were propagated and titrated in $\mathrm{Sf} 9$ cells as described previously (35). The construction and isolation of 373-t-PA were accomplished by established methods (35) as described elsewhere (V. A. Luckow and M. D. Summers, Virology, in press).

Infections and metabolic labeling. Sf9 cells were seeded at $10^{6}$ cells and allowed to attach to the plastic culture vessel for at least $1 \mathrm{~h}$ at $28^{\circ} \mathrm{C}$. The medium was drained, and $1.0 \mathrm{ml}$ of virus suspension was added to a multiplicity of infection of about 50 PFU per cell. The cells were incubated for another hour at $28^{\circ} \mathrm{C}$, the inoculum was removed, and the infected cells were fed with about $5 \mathrm{ml}$ of Grace medium containing $0.5 \%$ heat-inactivated fetal bovine serum and antibiotics (maintenance medium; D. Broussard and $\mathbf{M}$. Summers, J. Invert. Pathol., in press). The generic metabolic labeling procedure was to incubate the cells at $28^{\circ} \mathrm{C}$ until $20 \mathrm{~h}$ postinfection (hpi), remove the medium, and label the cells for $4 \mathrm{~h}$ with methionine-free Grace medium containing $100 \mu \mathrm{Ci}$ of Translabel (ICN Biomedicals, Inc., Irvine, Calif.; a mixture of about $80 \%\left[{ }^{35} \mathrm{~S}\right]$ methionine and about $20 \%\left[{ }^{35}\right.$ S $]$ cysteine; specific activity, about $1,200 \mathrm{Ci} / \mathrm{mmol}$ ) per ml. For inhibitor experiments, the labeling period was preceeded by a 4-h pretreatment, and the inhibitors were included in the labeling medium.
For pulse-chase analyses, we used a method adapted by C. Oker-Blom and M. Summers (submitted for publication). Sf9 cells were grown as suspension instead of monolayer cultures, and an appropriate number of cells were pelleted gently, suspended in $1.0 \mathrm{ml}$ of virus suspension at a multiplicity of infection of about 50 PFU per cell, and incubated for $1 \mathrm{~h}$ at $28^{\circ} \mathrm{C}$. The infected cells were pelleted, the inoculum was removed, and the cells were suspended in maintenance medium and incubated at $28^{\circ} \mathrm{C}$ until $23 \mathrm{hpi}$. At that time, the infected cells were pelleted, suspended in methionine-free Grace medium, and incubated for $1 \mathrm{~h}$ at $28^{\circ} \mathrm{C}$. Following this starvation period, the cells were pulselabeled either for $5 \mathrm{~min}$ with $500 \mu \mathrm{Ci}$ of Translabel per $\mathrm{ml}$ or for $15 \mathrm{~min}$ with $200 \mu \mathrm{Ci}$ of Translabel per $\mathrm{ml}$ in methioninefree Grace medium. After being labeled, the cells were immediately diluted 1:10 in chase medium (Grace medium containing $0.5 \%$ heat-inactivated fetal bovine serum, $5 \times$ concentrated amino acids, and $10 \mu \mathrm{g}$ of cycloheximide per $\mathrm{ml}$ ), pelleted, and resuspended in fresh chase medium. Zero-time samples were taken at this point, the cells were returned to $28^{\circ} \mathrm{C}$, and samples were removed at different times according to the requirements of the experiment.

Extractions, immunoprecipitation, gel electrophoresis, and Western blot (immunoblot) analysis. After pulse-label or pulse-chase, cellular fractions were prepared and t-PA was analyzed by immunoprecipitation and sodium dodecyl sulfate-polyacrylamide gel electrophoresis (SDS-PAGE) or by SDS-PAGE and Western blotting. The three cellular fractions of interest are defined here as extracellular, intracellular, and insoluble. The extracellular fraction consisted of the labeling medium recovered from the cells, clarified for 0.5 min in a microcentrifuge (model 235C; Fisher Scientific Co., Pittsburgh, Pa.), and supplemented with Nonidet P-40 (NP40 ) to a final concentration of $1 \%$. The intracellular fraction was prepared by treating the cells for $20 \mathrm{~min}$ on ice with extraction buffer ( $50 \mathrm{mM}$ Tris hydrochloride [pH 8.0] containing $100 \mathrm{mM} \mathrm{NaCl}, 1 \% \mathrm{NP}-40$, and 500 Kallikrein inactivating units of aprotinin per $\mathrm{ml}$ ), microcentrifuging the extract for $15 \mathrm{~min}$, and harvesting the supernatant fluid. The insoluble fraction was prepared by boiling the pellet from the intracellular fraction for $5 \mathrm{~min}$ in protein sample buffer (50 $\mathrm{mM}$ Tris hydrochloride [pH 6.8] containing 4\% SDS and 4\% $\beta$-mercaptoethanol), diluting $1: 100$ in extraction buffer, microcentrifuging the extract for $15 \mathrm{~min}$, and harvesting the supernatant fluid.

Immunoprecipitations were performed by incubating extracts overnight on ice with goat anti-human melanoma t-PA immunoglobulin G (American Diagnostica, New York, N.Y.) or rabbit anti-polyhedrin at a final concentration of 2.5 $\mu \mathrm{g} / \mathrm{ml}$. Immune complexes were harvested by adding $0.1 \mathrm{ml}$ of a fixed Staphylococcus aureus Cowan 1 suspension prepared by the method of Kessler (13), shaking the mixture for $30 \mathrm{~min}$ on ice, and washing the immunoprecipitates three times with a detergent wash buffer (extraction buffer supplemented with $0.1 \%$ SDS and $1 \%$ sodium deoxycholate). The washed immunoprecipitates were disrupted by being boiled for $3 \mathrm{~min}$ in protein sample buffer, the samples were clarified, and the supernatants were analyzed by SDS-PAGE with the discontinuous system of Laemmli (18). Autoradiograms were obtained by direct exposure of the dried gels to XAR-5 film (Eastman Kodak Co., Rochester, N.Y.) at room temperature.

For Western analysis (40), proteins separated by SDSPAGE were electrophoretically transferred to nitrocellulose sheets with a semidry apparatus in accordance with the recommendations of the manufacturer (American Bionetics, 
Inc., Hayward, Calif.). After transfer, the sheets were treated with blocking buffer $(25 \mathrm{mM}$ Tris hydrochloride [ $\mathrm{pH}$ 7.4] containing $0.14 \mathrm{M} \mathrm{NaCl}, 0.1 \% \mathrm{NP}-40,1 \%$ nonfat dry milk, and $0.02 \% \mathrm{NaN}_{3}$ ) for at least $1 \mathrm{~h}$ at room temperature and probed for $30 \mathrm{~min}$ at room temperature with goat anti-human t-PA at a dilution of 1:500 in blocking buffer. The sheets were washed three times with blocking buffer and treated for another $30 \mathrm{~min}$ at room temperature with alkaline phosphatase-conjugated rabbit anti-goat immunoglobulin $\mathrm{G}$ (Organon Teknika, Malvern, Pa.). After three more washes with blocking buffer, the sheets were rinsed with $25 \mathrm{mM}$ Tris hydrochloride [ $\mathrm{pH} 7.4$ ] containing $0.14 \mathrm{M} \mathrm{NaCl}$, blotted, and developed with a standard alkaline phosphatase color reaction (1).

Endoglycosidase reactions. Endo-H and N-glycanase were obtained from Genzyme, Inc. (Boston, Mass.). t-PA was immunoprecipitated from extracellular or intracellular fractions of 373-t-PA-infected Sf9 cells as described above, except that antigen-antibody complexes were disrupted by being boiled in $0.5 \%$ SDS and $0.1 \mathrm{M} \beta$-mercaptoethanol, prepared in water. The disrupted samples were clarified, and the supernatant fluid was harvested and diluted threefold with $50 \mathrm{mM}$ sodium phosphate ( $\mathrm{pH} 5.5$ ). Endo-H was added to a final concentration of $200 \mathrm{mU} / \mathrm{ml}$ or N-glycanase was added to a final concentration of $40 \mathrm{U} / \mathrm{ml}$, and the mixtures were incubated for at least $16 \mathrm{~h}$ at $37^{\circ} \mathrm{C}$. After the treatment period, the samples were boiled in an equal volume of $2 \times$-concentrated protein sample buffer and analyzed by SDS-PAGE.

\section{RESULTS}

Specific immunodetection of human t-PA expressed in insect cells. Relative to many other recombinant proteins that have been expressed with baculovirus vectors, t-PA is expressed at low levels (Luckow and Summers, in press). Therefore, it was desirable to establish a radioimmunoprecipitation procedure for the specific detection of t-PA-related polypeptides. The results (Fig. 1) of multiple experiments showed that polyclonal goat anti-t-PA serum precipitated only one extracellular polypeptide of about $62 \mathrm{kDa}$ (lane 8) and predominantly one intracellular polypeptide of about $65 \mathrm{kDa}$ (lane 10) from 373-t-PA-infected Sf9 cells. The vast majority of the intracellular t-PA was extractable with NP-40, as only small additional amounts were extracted from the residual NP-40-insoluble fraction by boiling in SDS plus mercaptoethanol (lane 12). Immunoprecipitation of the $62-$ and $65-\mathrm{kDa}$ proteins was specific, as evidenced by their absence in samples from mock-infected (lanes 1 to 6 ) or wild-type baculovirus (AcMNPV)-infected (lanes 13 to 18) cells immunoprecipitated with either anti-polyhedrin (odd lanes) or anti-t-PA (even lanes) and in samples from 373-t-PA-infected cells immunoprecipitated with anti-polyhedrin (lanes 7, 9, and 11). Conversely, minor amounts of several other proteins were nonspecifically precipitated from the intracellular fraction of 373-t-PA-infected Sf9 cells by anti-t-PA, as evidenced by their presence in control samples (e.g., with anti-polyhedrin in lane 9) and their nonreactivity with antit-PA in Western analyses (data not shown).

These results indicate that the $65-\mathrm{kDa}$ polypeptide is the major form of t-PA expressed in 373-t-PA-infected Sf9 cells and that the $62-\mathrm{kDa}$ polypeptide is the major form secreted from the cells. The masses of both proteins fall within the range of values reported for the $\mathrm{N}$-glycosylated single-chain forms of t-PA from mammalian cells. It should be noted that aprotinin was included in all extraction buffers to inhibit the

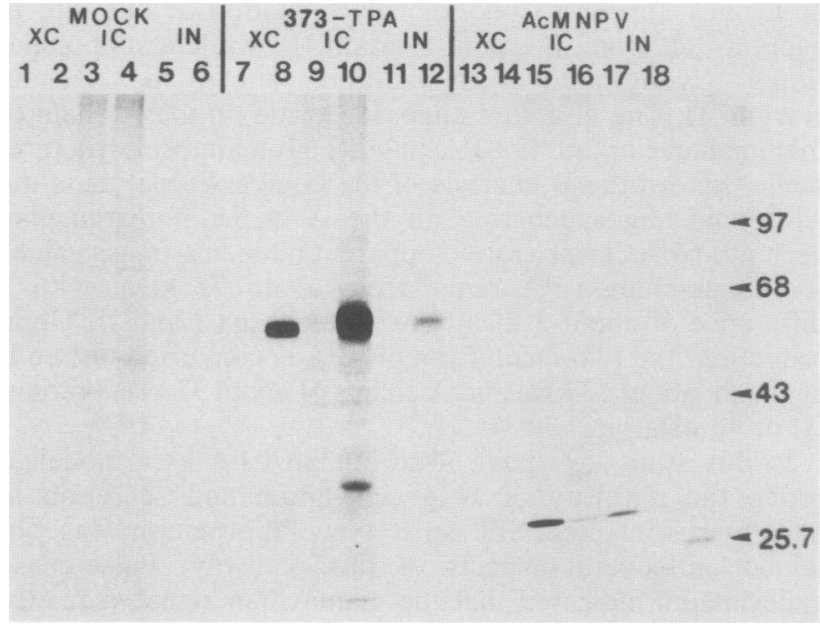

FIG. 1. Specific immunodetection of human t-PA in 373-t-PAinfected Sf 9 cells. Mock-, 373-t-PA-, or AcMNPV-infected Sf9 cells were pulse-labeled with $100 \mu \mathrm{Ci}$ of $\left[{ }^{35} \mathrm{~S}\right] \mathrm{Translabel}$ per ml from 20 to 24 hpi. Extracellular (XC), intracellular (IC), and insoluble (IN) fractions were prepared, and each was immunoprecipitated with either polyclonal rabbit anti-polyhedrin serum (odd lanes) or polyclonal goat anti-t-PA serum (even lanes). Immune complexes were adsorbed with fixed $S$. aureus Cowan 1 cells, washed, disrupted, and analyzed by SDS-PAGE. The numbers on the right or left represent molecular masses (in thousands) of standards run on each gel.

proteolytic conversion of the single-chain forms of t-PA to the smaller two-chain products (42). Nevertheless, we occasionally observed minor amounts of the reduced two-chain products, seen in Fig. 1 as the specifically precipitated intracellular protein of about $33 \mathrm{kDa}$ (lane 10).

Glycosylation of human t-PA expressed in insect cells. Treatments with endo- $\mathrm{H}$ or $\mathrm{N}$-glycanase were performed to determine directly if t-PA underwent $\mathbf{N}$ glycosylation in Sf9 cells. Endo-H removes only high-mannose $\mathrm{N}$-linked oligosaccharides from glycoproteins, while $\mathrm{N}$-glycanase [peptide- $\mathrm{N}^{4}-(N$-acetyl- $\beta$-glucosaminyl)asparagine amidase; 37] removes both high-mannose and complex $\mathrm{N}$-linked oligosaccharides from glycoproteins. Tunicamycin (TM), a well-established inhibitor of all $\mathrm{N}$ glycosylation (36), was used to obtain nonglycosylated t-PA from 373-t-PA-infected cells as a marker. Among several major bands immunoprecipitated from TM-treated cells with anti-t-PA (e.g., see Fig. $2 \mathrm{~A}$, lane 4 ), only the one with a mass of about $58 \mathrm{kDa}$ was specific, as shown by Western analysis (e.g., see Fig. 5). The other major bands observed in the presence of TM $(80,52$, 32 , and $31 \mathrm{kDa}$ ) might have been viral or cellular polypeptides which coprecipitated by virtue of a physical association with nonglycosylated t-PA; this possibility is under further investigation.

Treatment of the intracellular form of t-PA (Fig. 2A) with either endo-H (lane 6) or N-glycanase (lane 5) clearly reduced its size relative to the control (lane 7). These results indicate that intracellular t-PA is $\mathrm{N}$ glycosylated in $\mathrm{Sf} 9$ cells and that it contains high-mannose oligosaccharides. Similar results were obtained by treatment of the extracellular form of t-PA with these two endoglycosidases. Furthermore, it was clear that the product of $\mathrm{N}$-glycanase cleavage (lane 3 ) was smaller than that of endo-H cleavage (lane 2 ). This was probably true for intracellular t-PA as well, but with a smaller difference in the sizes of the endo- $\mathrm{H}$ and $\mathrm{N}$-glycanase reaction products (compare lanes 5 and 6). These 


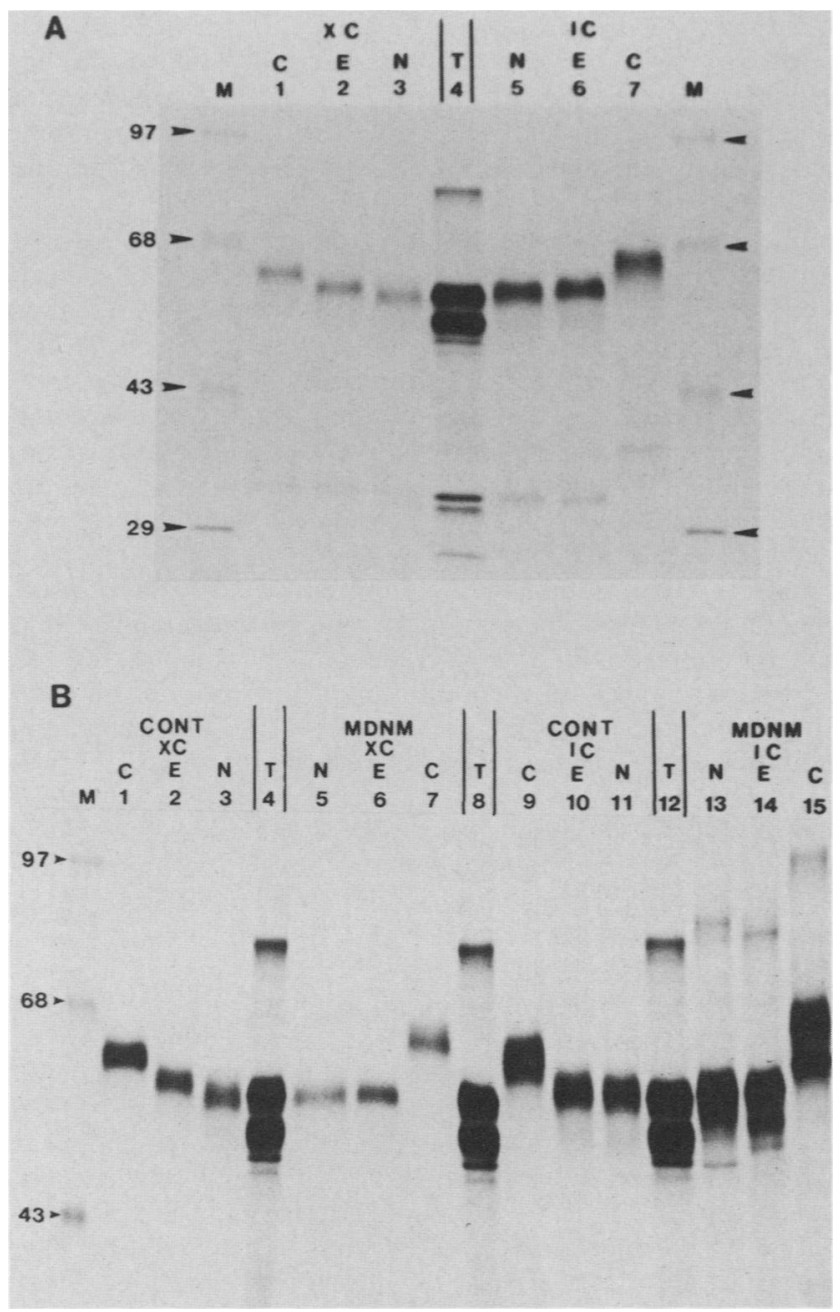

FIG. 2. Endoglycosidase analysis of insect cell-derived t-PA. 373-t-PA-infected Sf9 cells were labeled with ${ }^{35}$ S]Translabel, and t-PA was immunoprecipitated from the extracellular (XC) and intracellular (IC) fractions as described in the legend to Fig. 1. Immune complexes were washed, and t-PA was recovered and treated with buffer alone (C), $200 \mathrm{mU}$ of endo-H (E) per $\mathrm{ml}$, or $40 \mathrm{U}$ of $\mathrm{N}$-glycanase $(\mathrm{N})$ per $\mathrm{ml}$ as described in Materials and Methods. The reaction products were disrupted and analyzed by SDS-PAGE. t-PA immunoprecipitated from the intracellular fraction of infected Sf9 cells treated for $8 \mathrm{~h}$ with $1 \mu \mathrm{g}$ of TM (T) per ml (lanes 4,8 , and 12) served as a marker for the nonglycosylated protein. Note that only the upper band of the intense doublet from TM-treated cells (58 $\mathrm{kDa}$ ) was antigenically related to t-PA (e.g., see the Western analysis in Fig. 5B). (A) Analysis of t-PA from untreated cells. (B) Analysis of t-PA from untreated cells (CONT; lanes 1 to 3 and 9 to 11 ) and of t-PA from cells treated for $8 \mathrm{~h}$ with $2 \mathrm{mM}$ MDNM (lanes 5 to 7 and 13 to 15 ). Lane $M$ contained molecular mass standards (numbers at left in thousands).

results indicate that at least a subset of the $\mathrm{N}$-linked oligosaccharides in Sf9 cell-derived t-PA is partially resistant to endo- $\mathrm{H}$; therefore, some processing of these oligosaccharides has occurred in Sf9 cells. This observation was reproducible; multiple experiments with different passages of virus and cells, different lots and concentrations of both enzymes, and numerous independent SDS-PAGE analyses produced the same results.

A simple way to test the interpretation that $\mathrm{S} 9$ cells can process some $\mathrm{N}$-linked oligosaccharides arose from studies designed to examine the influence of oligosaccharide processing on the secretion of t-PA from these cells (see below). Both castanospermine and $\mathrm{N}$-methyldeoxynojirimycin (MDNM) are inhibitors of the cellular glucosidases that mediate the initial steps in the processing of $\mathrm{N}$-linked oligosaccharides (reviewed in reference 7). Neither of these inhibitors prevented the secretion of t-PA from Sf9 cells (see below). Thus, we were able to examine the endoglycosidase sensitivity of a t-PA population for which oligosaccharide processing had been artificially prevented. According to the interpretation of the endoglycosidase results presented above, t-PA from castanospermine- or MDNM-treated cells should have been equally sensitive to both endo- $\mathrm{H}$ and $\mathrm{N}$-glycanase; this was indeed the case (Fig. 2B). Endo-H or $\mathrm{N}$-glycanase treatment of the extracellular t-PA from MDNM-treated cells produced the same $58 \mathrm{kDa}$ end product (lanes 5 and 6), while the extracellular t-PA from control cells was, again, partially resistant to endo-H (lanes 1,2 , and 3). Identical results were obtained in endoglycosidase analyses of t-PA isolated from castanospermine-treated cells (data not shown). These results strongly support the interpretation that at least a subset of the N-linked oligosaccharides of human t-PA expressed in Sf9 cells has been processed to an endo-H-resistant form.

Another conclusion to be drawn from the endoglycosidase experiments is that the difference in the sizes of the intracellular and extracellular forms of t-PA is not related to $\mathbf{N}$ glycosylation, because the completely deglycosylated forms (N-glycanase reaction products) are still different in size. Therefore, these two forms of t-PA probably differ in their primary structures. One speculation is that the intracellular form still contains the prosequence of about 15 amino acids, while the secreted form does not. This model requires that the product synthesized in the presence of TM also lacks the prosequence to explain its comigration with the deglycosylated extracellular product and the fact that it is smaller than the deglycosylated intracellular product. Proteolytic removal of the prosequence of intracellular nonglycosylated t-PA might be anticipated on the basis of increased sensitivity of the polypeptide to proteolysis in the absence of $\mathrm{N}$ glycosylation $(22,23)$.

Kinetics of t-PA glycosylation and secretion in Sf9 cells. Pulse-chase analyses were used to evaluate the kinetics with which human t-PA entered and exited the secretory pathway in baculovirus-infected $\mathrm{Sf} 9$ cells. Infected cell cultures were pulse-labeled for 5 or $15 \mathrm{~min}$ at $24 \mathrm{hpi}$ and chased in the presence of excess amino acids and $10 \mu \mathrm{g}$ of cycloheximide per $\mathrm{ml}$ as described in Materials and Methods. Samples were removed from the cultures at various intervals and clarified, and t-PA was isolated from the extracellular and intracellular fractions by immunoprecipitation and analyzed by SDSPAGE. In the absence of an inhibitor (e.g., TM), a nonglycosylated form of t-PA was never detected, even when the cells were labeled for only $5 \mathrm{~min}$ (Fig. 3). In control experiments, we found that the mass of t-PA synthesized in vitro was clearly different from that of $t-P A$ isolated from the intracellular fraction of 373-t-PA-infected Sf9 cells, proving that a nonglycosylated form of t-PA could have been detected (data not shown). Thus, recognition of the mammalian t-PA signal sequence occurs with high efficiency in Sf9 cells, followed by rapid translocation across the membrane of the rough endoplasmic reticulum and $\mathrm{N}$ glycosylation, probably in a cotranslational fashion. The data do not eliminate the theoretical possibility, however, that signal sequence recognition is followed by translational arrest without reinitiation. Therefore, although the pulse-chase experiments indicate 


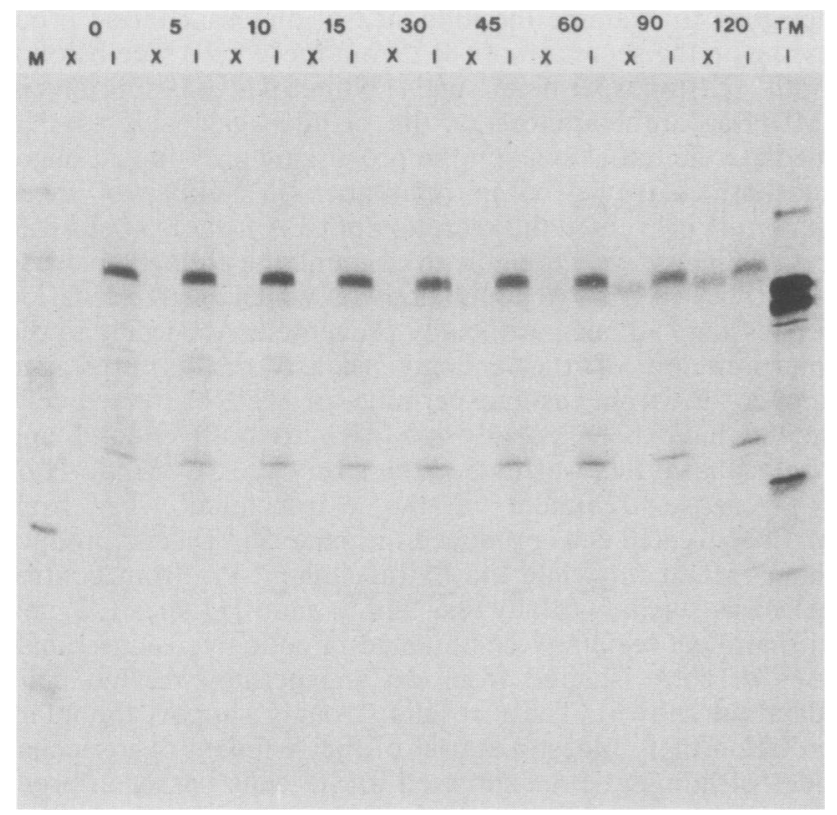

FIG. 3. Pulse-chase analysis of t-PA biosynthesis and secretion. 373-t-PA-infected Sf9 cells cultured in suspension were pulselabeled for $5 \mathrm{~min}$ at $24 \mathrm{hpi}$ with $500 \mu \mathrm{Ci}$ of $\left[{ }^{35} \mathrm{~S}\right] \mathrm{Translabel}$ per $\mathrm{ml}$ and chased as described in Materials and Methods. Samples were taken immediately after the labeling period $(0 \mathrm{~min})$ or at various times afterwards (numbers at the top indicate time in minutes), and t-PA was immunoprecipitated from the extracellular $(\mathrm{X})$ or intracellular fractions (I) and analyzed by SDS-PAGE. t-PA immunoprecipitated from TM-treated cells served as a marker for nonglycosylated t-PA, as indicated in the legend to Fig. 2. Lane M is as in Fig. 2.

that recognition of the t-PA signal sequence is an efficient process, they cannot provide a true measure of the efficiency with which newly synthesized t-PA molecules enter the secretory pathway.

With chase times of up to 2 (Fig. 3) or even 16 (data not shown) $h$, there was no apparent change in the mass of t-PA in the intracellular fraction; the smaller form of t-PA was detected only in the extracellular fraction. This result suggests that conversion of the larger form of t-PA to the smaller form, which is probably not related to $\mathrm{N}$ glycosylation, occurs simultaneously with or shortly after its exit from the cell.

The rate of secretion of human t-PA from 373-t-PAinfected Sf 9 cells was determined from pulse-chase experiments by quantitation of the $62 \mathrm{kDa}$ extracellular t-PA bands as a function of chase time (Fig. 4). The results indicate that the secretion of t-PA occurs rather slowly, with a half-time of about $1.6 \mathrm{~h}$. In light of the apparent rapidity of translocation and $\mathrm{N}$ glycosylation, this result suggests that a ratelimiting step(s) in the secretion of t-PA occurs later, during the subsequent processing of the polypeptide and its movement out of the Sf 9 cell.

Role of glycosylation in the secretion of t-PA from insect cells. TM was used to evaluate the role of $\mathrm{N}$ glycosylation in the secretion of t-PA from Sf9 cells. The conditions of TM treatment required for the inhibition of $\mathbf{N}$ glycosylation were established by measuring the incorporation of either $\left[{ }^{35} \mathrm{~S}\right]$ methionine or $\left[{ }^{3} \mathrm{H}\right]$ mannose into total acid-precipitable protein from 373-t-PA-infected Sf9 cells. The results showed that an 8-h treatment with $1.0 \mu \mathrm{g}$ of TM per ml provided $79 \%$ inhibition of control mannose incorporation, with no inhibition of overall protein synthesis; in fact, a minor stimulation (114\% of the control) was observed (data not shown). Under these conditions, virtually no extracellular t-PA was detectable by either immunoprecipitation (Fig. 5A) or Western analysis (Fig. 5B). In addition, t-PA accumulated with an altered intracellular distribution within the TM-treated Sf9 cells; significant amounts were extractable from the NP-40insoluble fraction of TM-treated cells, while very little was extractable from the NP-40-insoluble fraction of untreated cells (Fig. 5B). These results indicate that the nonglycosylated t-PA product is not secreted from TM-treated Sf 9 cells; instead, it appears to associate with an insoluble subcellular compartment. This model is consistent with the observation that several different polypeptides were strongly immunoprecipitated from the intracellular fraction of TM-treated

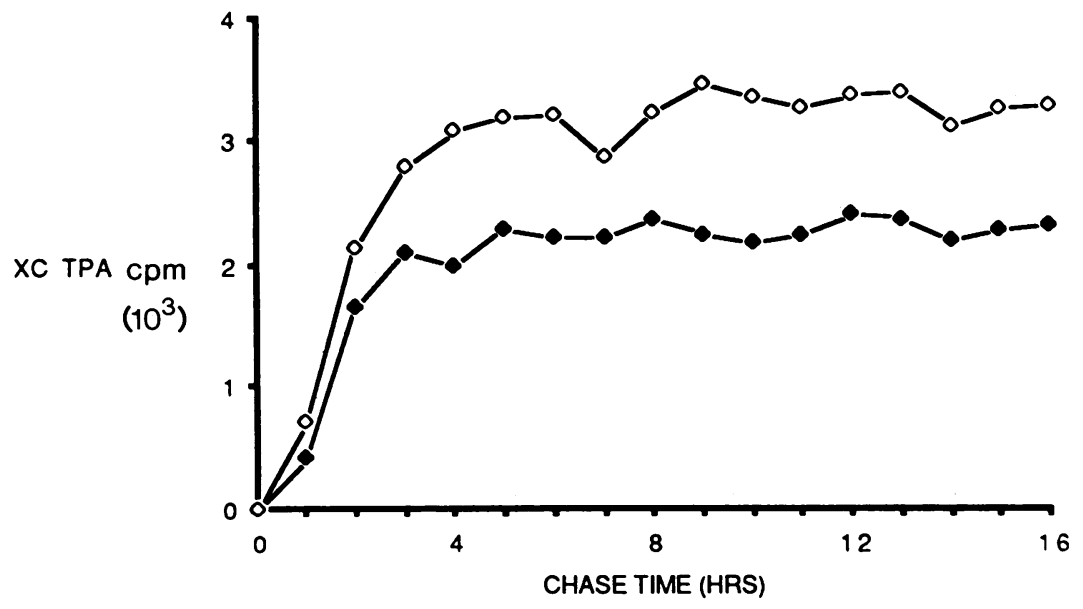

FIG. 4. Kinetics of t-PA secretion from Sf9 cells. Duplicate cultures of 373-t-PA-infected Sf9 cells cultured in suspension were pulse-labeled for $15 \mathrm{~min}$ at $24 \mathrm{hpi}$ with $200 \mu \mathrm{Ci}$ of $\left[{ }^{35} \mathrm{~S}\right]$ Translabel per $\mathrm{ml}$ and chased as described in Materials and Methods. Samples were taken immediately after the labeling period or after various times of chase, and t-PA was immunoprecipitated from the extracellular fraction. The immunoprecipitates were resolved by SDS-PAGE, and t-PA bands were excised, solubilized, and quantitated by liquid scintillation spectroscopy. Results were plotted as total extracellular t-PA (XC TPA) versus chase time, with the values obtained for the zero-time samples subtracted as background. The two separate plots represent independent results obtained with the duplicate cultures. The half-time for secretion was determined separately from each curve and was found in both cases to be $1.6 \mathrm{~h}$. 


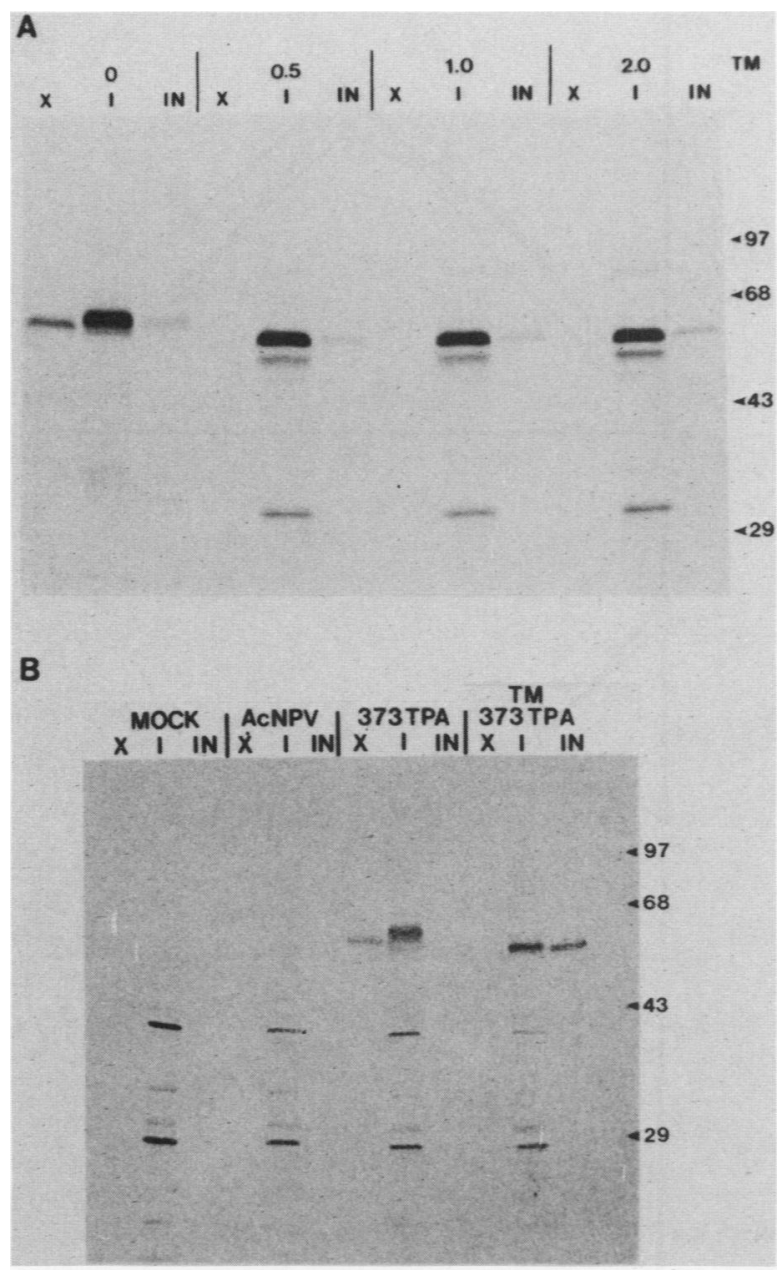

FIG. 5. Effect of TM treatment on t-PA secretion from Sf9 cells. (A) 373-t-PA-infected Sf9 cells were untreated (0) or treated for $8 \mathrm{~h}$ with $0.5,1.0$, or $2.0 \mu \mathrm{g}$ of TM per $\mathrm{ml}$, as indicated above the lanes. The cells were labeled with $100 \mu \mathrm{Ci}$ of $\left.{ }^{35} \mathrm{~S}\right] \mathrm{Translabel}$ per $\mathrm{ml}$ from 20 to $24 \mathrm{hpi}$, corresponding to the last half of the TM treatment period. Extracellular (X), intracellular (I), and insoluble (IN) fractions were prepared, and t-PA was immunoprecipitated and analyzed by SDS-PAGE. (B) Cells were mock infected or infected with wild-type baculovirus (AcMNPV) or 373-t-PA and were untreated or treated with $1.0 \mu \mathrm{g}$ of TM per $\mathrm{ml}$, as indicated above the lanes. Extracellular (X), intracellular (I), and insoluble (IN) fractions were prepared, and proteins were resolved directly by SDS-PAGE and analyzed by Western transfer with goat anti-t-PA as the probe as described in Materials and Methods. Numbers at right are as in Fig. 1.

cells (Fig. 5A), while only one polypeptide $(58 \mathrm{kDa}$ ) proved to be specifically immunoreactive (Fig. 5B). The other proteins might have been coimmunoprecipitated by virtue of a physical association with the $58-\mathrm{kDa}$ nonglycosylated $\mathrm{t}-\mathrm{PA}$ product, as noted above.

The biosynthesis and secretion of t-PA also were examined in Sf9 cells treated with inhibitors which interfere with the processing of $\mathrm{N}$-linked oligosaccharide side chains. The glucosidase inhibitors MDNM and castanospermine were clearly effective in $\mathrm{Sf} 9$ cells, as evidenced by changes in the mass of t-PA relative to the control (Fig. 6A). The specifically immunoreactive t-PA polypeptides were detected by Western analysis (Fig. 6B). A comparison of Fig. 6A and B reveals that several polypeptides were immunoprecipitated

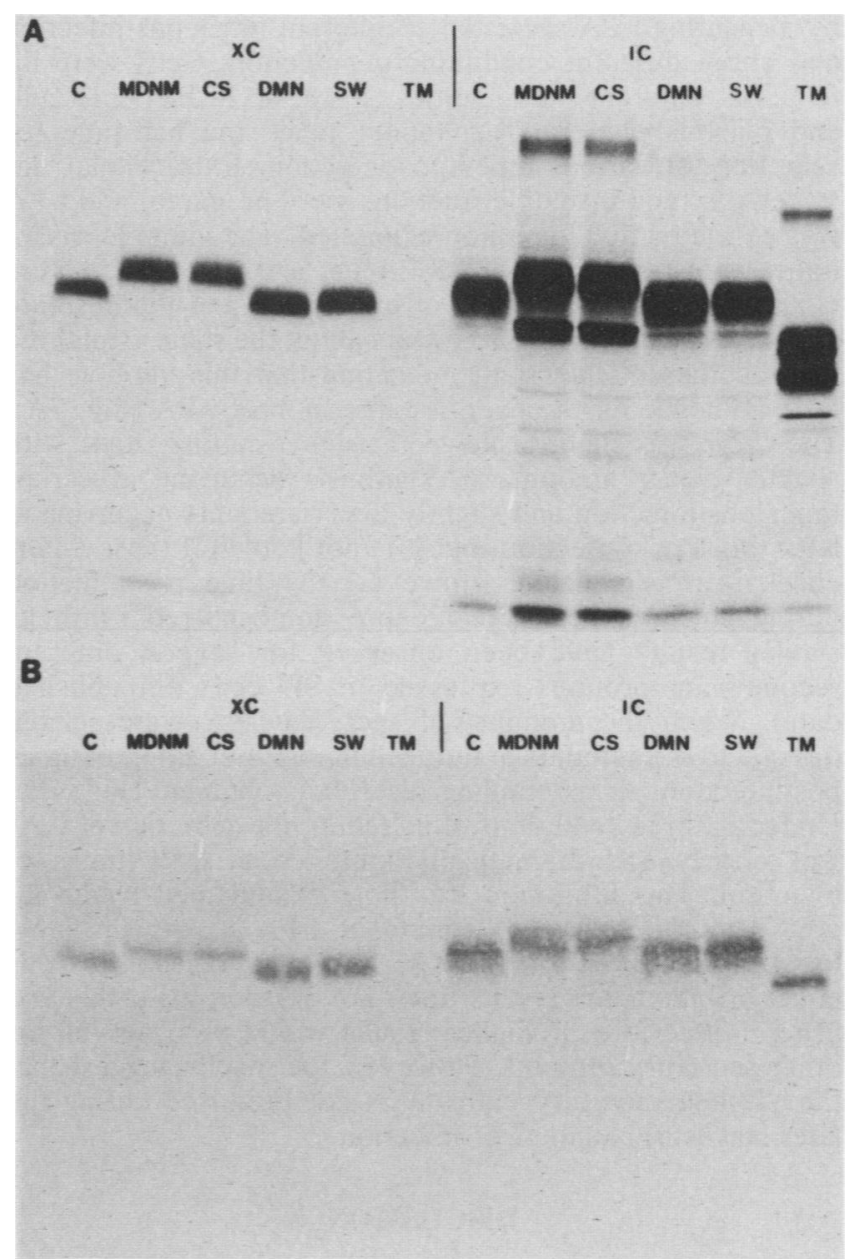

FIG. 6. Effects of oligosaccharide processing inhibitors on t-PA secretion from Sf9 cells. 373-t-PA-infected Sf9 cells were treated beginning at $16 \mathrm{hpi}$ with Grace medium alone (C) or with medium containing $2.0 \mathrm{mM}$ MDNM, $0.2 \mathrm{mM}$ castanospermine (CS), $1.0 \mathrm{mM}$ deoxymannojirimycin (DMN), $0.015 \mathrm{mM}$ swainsonine (SW), or $1 \mu \mathrm{g}$ of TM per ml. Each inhibitor was prepared as a $10 \times$ stock in Grace medium, except for TM, which was prepared as a $1,000 \times$ stock in ethanol, and inhibitors were stored at $-70^{\circ} \mathrm{C}$ prior to use. All inhibitors were purchased from Genzyme, except for castanospermine and TM, which were purchased from Behring Diagnostics (San Diego, Calif.). The cells were labeled with $100 \mu \mathrm{Ci}$ of $\left[{ }^{35} \mathrm{~S}\right] \mathrm{Translabel}$ per $\mathrm{ml}$ from 20 to $24 \mathrm{hpi}$, and extracellular (XC) and intracellular (IC) fractions were prepared. (A) t-PA was immunoprecipitated from the cell fractions and analyzed by SDS-PAGE. (B) Total proteins in fractions were resolved by SDS-PAGE and subjected to Western analysis with goat anti-t-PA as the probe as described in Materials and Methods.

nonspecifically from inhibitor-treated cells, as was observed for TM-treated cells. However, none of the inhibitors prevented secretion of the incompletely processed glycoprotein. Furthermore, unlike TM, these inhibitors had no effect on the solubility of intracellular t-PA (data not shown). These findings suggest that, although $\mathrm{N}$ glycosylation in Sf9 cells is required directly or indirectly for the secretion of t-PA, processing of the $\mathrm{N}$-linked oligosaccharide side chains is not.

Influence of virus infection on the secretion of t-PA from insect cells. The influence of the ongoing baculovirus infection on the processing of t-PA in insect cells was evaluated 
Mol. Cell. Biol.

by measuring t-PA secretion at different times postinfection and under different conditions of infection. Cells were infected at different multiplicities $(1,10$, or 20 PFU per cell) and pulse-labeled for $4 \mathrm{~h}$ (about twice the half-time for secretion) at various times postinfection. Extracellular, intracellular, and insoluble fractions were prepared, and t-PA was extracted and immunoprecipitated. The immunoprecipitates were resolved by SDS-PAGE, and t-PA bands were quantitated. The peak time of expression and the absolute amounts of t-PA synthesized were about the same at all three multiplicities of infection, indicating that this variable has little influence on the overall expression of t-PA (Fig. 7A). The curve was slightly skewed at higher multiplicities, with slightly higher amounts of synthesis occurring at earlier times postinfection and slightly lower amounts occurring at later times postinfection, but it is not known if these differences were significant. However, the time postinfection during which the peak rate of expression occurred is firm, as similar results have been observed for several different recombinant proteins expressed in Sf9 cells (unpublished data). When the amounts of secreted t-PA were related directly to the amounts of intracellular t-PA at different times postinfection, an astounding result was obtained (Fig. 7B). Under all three conditions of infection, the secretion of t-PA was clearly and dramatically inhibited at later times of infection. This inhibition was not accompanied by an increase in the relative amounts of t-PA in the insoluble intracellular fraction (Fig. 7C). The exact reasons for this effect are unknown at this time, nor is it known if this is a general effect; i.e. if similar results would be observed for other secretory proteins. However, the results suggest that the Sf9 cell secretory pathway is compromised during the later stages of baculovirus infection.

\section{DISCUSSION}

Human t-PA was expressed in Sf9 insect cells with a recombinant baculovirus vector and was used as a model to study the pathway of protein glycosylation and secretion in these cells. Formally, the results of this study apply directly only to human t-PA and Sf9 cells, the model glycoprotein and cell line for which the data were derived. However, we speculate that the results reflect the characteristics of the lepidopteran insect cell pathway which accomplishes $\mathrm{N}$ glycosylation and secretion of mammalian glycoproteins in general and probably of naturally occurring insect glycoproteins as well.

The major intracellular form of human t-PA expressed in baculovirus-infected $\mathrm{Sf} 9$ cells was a polypeptide of about 65 $\mathrm{kDa}$, and it was secreted as a slightly smaller product of about $62 \mathrm{kDa}$. A nonglycosylated t-PA precursor was not detected intracellularly, even with short times of pulselabeling. This indicated that the signal sequence of human t-PA was efficiently recognized in $\mathrm{Sf} 9$ cells and that one result of this was the rapid translocation of the nascent polypeptide across the rough endoplasmic reticulum membrane, where it became immediately available for $\mathbf{N}$ glycosylation. Many other mammalian glycoproteins have been shown to undergo $\mathrm{N}$ glycosylation and secretion when expressed in Sf 9 cells by baculovirus vectors (reviewed in reference 19), so this was not a surprising result. The unexpected result was that the extracellular form of t-PA was partially resistant to treatment with endo-H. In contrast to the results of previous studies of mammalian glycoproteins expressed in $\mathrm{Sf} 9$ cells by baculovirus vectors $(10,17$, 28,44 ; reviewed in reference in 19), this finding suggested
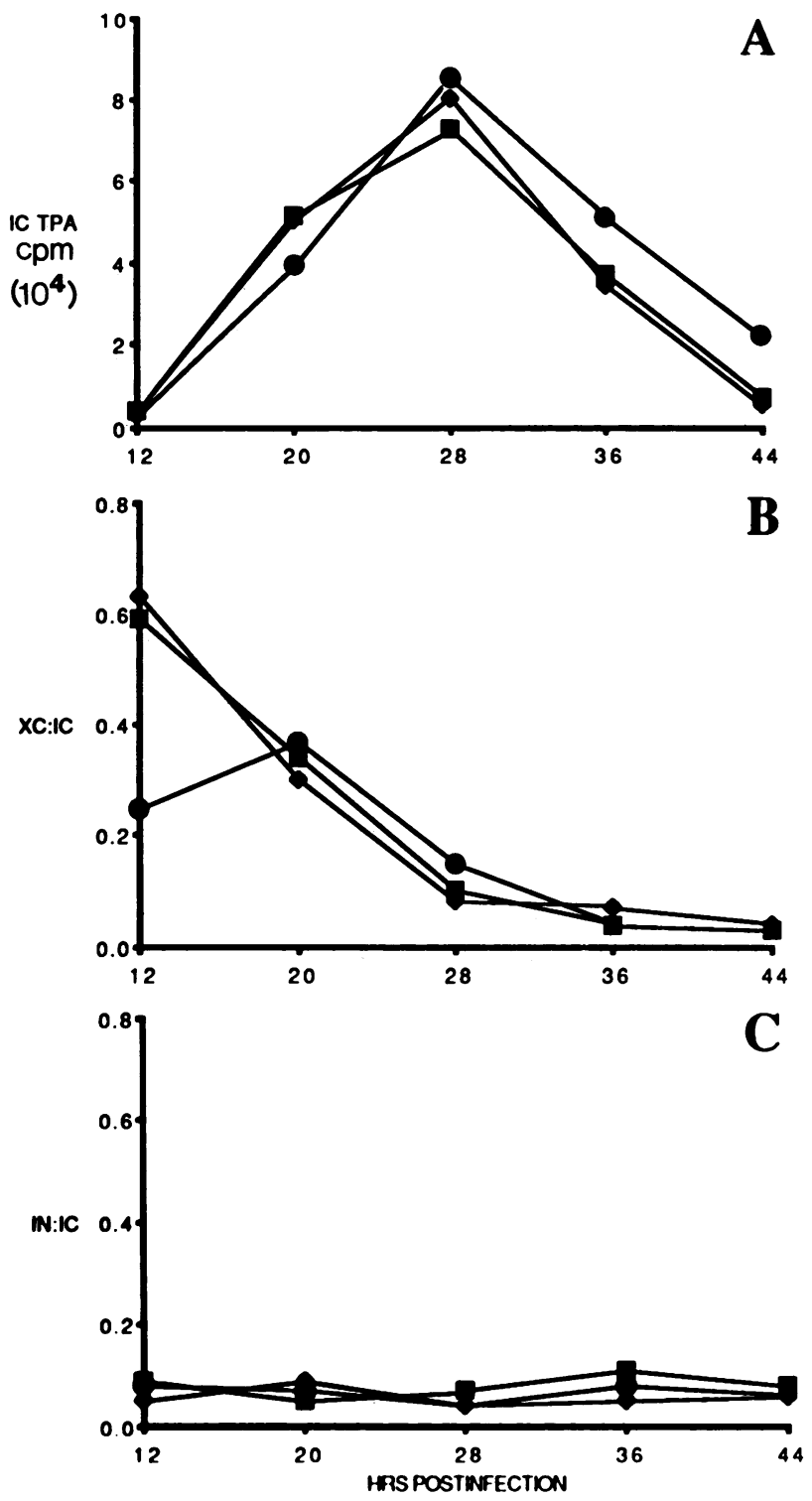

FIG. 7. Influence of virus infection on t-PA secretion. Sf9 cells were infected with 373-t-PA at multiplicities of infection of $1(\bullet), 10$ $(\$)$, or 20 (ם) PFU per cell and labeled for $4 \mathrm{~h}$ with $100 \mu \mathrm{Ci}$ of ${ }^{35}$ S]Translabel per ml from 12 to 16,20 to 24,28 to 32,36 to 40 , or 44 to $48 \mathrm{hpi}$. After the labeling period, t-PA was immunoprecipitated from extracellular (XC), intracellular (IC), and insoluble (IN) fractions and was gel purified, and the t-PA bands were excised, solubilized, and quantitated by liquid scintillation spectroscopy. (A) Plot of total intracellular t-PA (IC TPA) as a function of time postinfection. (B) Plot of the ratio of extracellular to intracellular t-PA at various times postinfection. (C) Plot of the ratio of insoluble to intracellular t-PA at various times postinfection.

that a high-mannose $\mathrm{N}$-linked oligosaccharide may be processed to an endo-H-resistant form in these cells.

The precise structure of the endo-H-resistant oligosaccharide(s) on the $62 \mathrm{kDa}$ t-PA polypeptide secreted from Sf9 cells was not determined. In mammalian cells, resistance to endo- $\mathrm{H}$ is acquired by the conversion of an oligosaccharideprocessing intermediate, [Asn]-GlcNAc $-\mathrm{Man}_{5}$, to [Asn]$\mathrm{GlcNAc}_{2}-\mathrm{Man}_{3}-\mathrm{GlcNAc}$ by mannosidase II and $\mathrm{N}$-acetylglucosaminyltransferase $I$ in the medial compartment of the Golgi apparatus (reviewed in references 8 and 14). It is 
possible that a similar conversion takes place in Sf9 cells. However, previous studies of mosquito and fruitfly cells suggest that the processing of $\mathrm{N}$-linked glycans is different in insects; in these dipteran cells, the cotranslational addition of a typical high-mannose oligosaccharide, GlcNAc $\mathbf{2}_{-}-\mathrm{Man}_{\mathbf{9}}-$ $\mathrm{Glc}_{3}$, is followed by the processing of about half of the total $\mathrm{N}$-linked glycans to a trimannosyl core, [Asn]-GlcNAc - $^{-}$ $\mathrm{Man}_{3}$ (12). Further processing of the oligosaccharide does not appear to take place, owing to the absence of the requisite glycosyltransferase activities (5). If Sf9 cells also lack these glycosyltransferase activities, then the trimannosyl core probably represents the fully processed oligosaccharide(s) on the extracellular form of t-PA, because it is endo-H resistant (39). Clearly, direct chemical analyses of the processed oligosaccharides will be necessary to elucidate their precise structures.

Although our endoglycosidase results show that a previously unrecognized degree of $\mathrm{N}$-linked oligosaccharide processing may occur in baculovirus-infected $\mathrm{Sf} 9$ cells, it must be emphasized that this probably does not occur for all $\mathrm{N}$ linked glycoproteins expressed in Sf9 cells or in other insect cells. Only about half of the oligosaccharides in mosquito cell glycoproteins contain a trimannosyl core structure; the other half contain endo-H-sensitive structures with variable numbers of mannose residues (12). The mature, secreted form of arylphorin, the major hemolymph glycoprotein of Manduca sexta (Lepidoptera), contains [Asn]-GlcNAc ${ }_{2}$ $\mathrm{Man}_{9}$, an endo-H-sensitive structure (30). Similarly, the mature forms of lipophorin, the major lipoprotein of the locust, Locusta migratoria (Orthoptera), contain endo-Hsensitive oligosaccharides with variable numbers of mannose residues from $\operatorname{Man}_{9}$ to $\operatorname{Man}_{5}$ (21). Finally, it has been shown that plasma membrane glycoproteins isolated from mosquito cells contain three terminal glucose residues, indicative of the transport of a completely nonprocessed glycoprotein through the secretory pathway (4).

Additional information on the steps that constitute the $\mathrm{N}$ glycosylation pathway in Sf9 cells was obtained by using inhibitors of $\mathrm{N}$-linked oligosaccharide processing. Both castanospermine and MDNM caused an increase in the size of intracellular t-PA, suggesting the presence of glucosidase I and/or II activities in Sf9 cells. This result is consistent with those of previous studies suggesting that terminal glucose residues may be trimmed from $\mathrm{N}$-linked oligosaccharides in insect cells, as noted above. Deoxymannojirimycin had no apparent affect on the size of t-PA, suggesting the absence of mannosidase I. However, this result is probably an artifactual one, as the removal of mannose residues has been clearly documented in previous studies $(12,21)$, and this must occur for an oligosaccharide to acquire endo-H resistance. This conclusion is supported by the observation that deoxymannojirimycin also fails to inhibit yeast mannosidase $I$ in vivo, even though it effectively inhibits the enzyme in vitro (16). Swainsonine caused a slight retardation of t-PA, suggesting the presence of mannosidase II activity in Sf9 cells, but not in a particularly convincing fashion. Direct analysis of $\mathrm{Sf} 9$ cell extracts for the presence of each of these putative enzymatic activities will be required to test these tentative interpretations.

Studies on the rate of secretion of t-PA from Sf9 cells indicated that this was a relatively slow process, with a half-time of about $1.6 \mathrm{~h}$. However, the absence of detectable nonglycosylated t-PA in the cells suggested that entry into the secretory pathway and $\mathrm{N}$ glycosylation occurred quickly. Thus, a rate-limiting step(s) in the secretion of t-PA from $\mathrm{Sf} 9$ cells probably occurs after translocation and $\mathrm{N}$ glycosylation. It is possible that folding of the polypeptide occurs slowly, as it contains 35 cysteine residues, some of which are thought to participate in intramolecular disulfide bonds to generate a complex folded structure (24). In previous studies, it has been shown that folding and/or supramolecular assembly is a prerequisite for the movement of two different viral glycoproteins through the secretory pathway of mammalian cells $(9,15)$.

After enzymatic deglycosylation, the extracellular and intracellular forms of t-PA still had different apparent molecular masses. This indicated that the difference in their masses was not related to a difference in $\mathrm{N}$ glycosylation. On the basis of comparisons to nonglycosylated t-PA produced in the presence of $\mathrm{TM}$, we speculated that the $65-\mathrm{kDa}$ intracellular form of $\mathrm{t}-\mathrm{PA}$ retains, while the $62-\mathrm{kDa}$ extracellular form lacks, the amino-terminal prosequence of about 15 amino acids. A putative t-PA prosequence was first identified from the nucleotide sequence by Pennica and coworkers (24), and its absence in the mature t-PA polypeptide secreted from mammalian cells has been shown by direct peptide sequencing (27). The fact that none of the $62-\mathrm{kDa}$ form was detected intracellularly suggests that the structural modification accounting for its lower mass occurs simultaneously with or shortly after its exit from the cell.

Treatment of 373-t-PA infected Sf9 cells with TM prevented the appearance of t-PA in the extracellular culture medium. In contrast, inhibitors of $\mathrm{N}$-linked oligosaccharide processing had no detectable effect on the secretion of t-PA from $\mathrm{Sf} 9$ cells. Together, these results suggest that $\mathrm{N}$ glycosylation, but not processing of the $\mathrm{N}$-linked oligosaccharides, is directly or indirectly required in Sf9 cells for the secretion of human t-PA. Previous studies have shown that TM reduces the secretion of a naturally occurring insect cell secretory glycoprotein, vitellogenin, in the cockroach, Blattella germanica (Orthoptera), by about $60 \%$ (45). Similarly, Charlton and Volkman (6) suggested that cell surface expression of the major AcMNPV glycoprotein, gP64, is diminished in IPLB-Sf $21-A E$ cells treated with TM. From all of these results, we tentatively speculate that N-linked carbohydrate plays a functional role in the movement of some glycoproteins through the secretory pathway of $S$. frugiperda cells and probably other insect cells as well. This clearly is not a universal rule, however, as at least one exception has already been described; a nonglycosylated form of phaseolin, a plant storage glycoprotein, is secreted from TM-treated Sf9 cells (3).

We do not know the mechanism by which $\mathrm{N}$-linked oligosaccharides function in the secretion of t-PA from Sf9 cells, but several possibilities may be addressed. One is that the glycan provides a direct signal which targets t-PA for secretion, possibly through recognition by a cellular receptor. However, if this were true, inhibitors of oligosaccharide processing would be expected to inhibit t-PA secretion, because the structure of the unprocessed glycan would be different from that of the processed glycan. A second possibility is that the oligosaccharides protect the polypeptide from proteolytic degradation, thereby influencing secretion in an indirect way. Protease inhibitors can restore secretion or cell surface expression of several mammalian glycoproteins in TM-blocked cells, supporting a protective role for $\mathrm{N}$-linked glycans $(22,23)$. However, we observed no difference when Sf9 cells were treated with either TM alone or TM and protease inhibitors (500 Kallikrein inactivating units of aprotinin per $\mathrm{ml}$ and $200 \mu \mathrm{M}$ leupeptin); in either case, there was no detectable extracellular t-PA (unpublished observations). A third possible mechanism is that a change in the 
physical properties of t-PA, such as its solubility in an aqueous solvent, occurs in the absence of $\mathrm{N}$ glycosylation and interferes with its progression through the Sf9 cell secretory pathway. The finding that nonglycosylated t-PA had an altered intracellular distribution, with unusually large amounts in the NP-40-insoluble fraction of TM-treated cells, is consistent with this possibility. Perhaps the nonglycosylated form of t-PA associates tightly with relatively insoluble cellular or viral polypeptides and this association inhibits the transit of the nonglycosylated polypeptide through the secretory pathway. This would explain why immunoprecipitation of the nonglycosylated product resulted in the detection of several other polypeptides which were antigenically unrelated to t-PA; as discussed above, these other proteins might have been coimmunoprecipitated by virtue of a physical association with nonglycosylated t-PA. A more speculative notion is that this mechanism exists by design for the removal of proteins recognized as aberrant by $\mathrm{Sf} 9$ cells. This might represent an insect cell homolog of the mammalian cell mechanism which is thought to prevent the premature export of proteins prior to their acquisition of appropriate supramolecular structure $(2,11,20)$. If so, one or more of the proteins coprecipitating with nonglycosylated t-PA could be an insect cell version of the immunoglobulin-heavy-chain-binding protein, $\operatorname{BiP}(2,11,20)$. Arguing against this mechanism is the observation that several proteins coprecipitated with t-PA from Sf9 cells treated with inhibitors of $\mathrm{N}$-linked oligosaccharide processing, even though none of these agents completely prevented the secretion of t-PA. Finally, a possible mechanism for the inhibition of t-PA secretion by TM treatment is that inhibition of $\mathrm{N}$ glycosylation by TM eliminates the function of a cellular protein(s) required for the process of protein secretion from Sf9 cells. On the basis of our current observations, we are unable to either support or refute this possibility.

Differences in the multiplicity of baculovirus infection did not appear to influence either the level of absolute expression or the relative amounts of secretion of human t-PA expressed in Sf9 cells. However, the relative amounts of secreted t-PA decreased dramatically with increasing time of infection. We speculate that this reflects a direct or indirect effect of baculovirus infection on the host cell secretory pathway. It is unlikely that the accumulation of t-PA simply overwhelms the Sf9 secretory apparatus, because t-PA was expressed at relatively low levels (Luckow and Summers, in press) and because the absolute, as well as the relative, amounts of secreted t-PA were lower at later times of infection. This suggests that one result of the Sf9-AcMNPV interaction is an inhibitory effect on the secretory pathway late in infection. With respect to the use of baculoviruses as vectors for foreign gene expression, these findings indicate that current vectors are suboptimal for the production of secretory glycoproteins. In the future, we will investigate ways to avoid late viral effects on host cells to optimize the baculovirus vector approach for the expression of mammalian secretory glycoproteins.

\section{ACKNOWLEDGMENTS}

This study was supported by Texas Agricultural Experiment Station project 6316 and Texas A\&M University Institute of Biosciences and Technology support grants.

We thank Mary Estes for valuable discussions during the course of this project.

\section{ADDENDUM IN PROOF}

While this manuscript was under review, we became aware that other investigators using the baculovirus expression system have recently found that $\mathrm{Sf} 9$ cells are capable of processing some $\mathrm{N}$-linked oligosaccharide side chains to a state of endo-H resistance. The specific glycoproteins for which this was documented include the ligand-binding domain of the human insulin receptor (J. Sissom and L. Ellis, submitted for publication), the extracellular domain of the rat myelin-associated glycoprotein (P. W. Johnson, J. Attia, C. D. Richardson, J. C. Roder, and R. J. Dunn, submitted for publication), and human acid $\beta$-glucosidase (G. A. Grabowski, W. R. White, and M. E. Grace, Enzyme, in press). For the insulin receptor and myelin-associated glycoprotein, the intracellular forms were completely endo- $H$ sensitive, while the extracellular forms displayed at least partial endo$\mathrm{H}$ resistance; secretion was accomplished in both cases by deletion of the transmembrane anchor domains. For acid $\beta$-glucosidase, the majority of the protein remained cell associated but still exhibited partial resistance to endo- $\mathrm{H}$. Thus, it is apparent that processing of the $\mathrm{N}$-linked oligosaccharides of several different mammalian glycoproteins can occur in $\mathrm{Sf} 9$ cells, strengthening the speculative conclusion that $\mathrm{Sf} 9$ cells behave like other insect cells (see references 4 , $5,12,21$, and 30 ) in this respect.

\section{LITERATURE CITED}

1. Blake, M. S., K. H. Johnston, G. J. Russell-Jones, and E. C. Gotschlich. 1984. A rapid, sensitive method for detection of alkaline phosphatase conjugated anti-antibody on Western blots. Anal. Biochem. 36:175-179.

2. Bole, D. G., L. M. Hendershot, and J. F. Kearney. 1986. Posttranslational association of immunoglobulin heavy chain binding protein with nascent heavy chains in nonsecreting and secreting hybridomas. J. Cell. Biol. 102:1558-1566.

3. Bustos, M., V. A. Luckow, L. R. Griffing, M. D. Summers, and T. C. Hall. 1988. Expression, glycosylation and secretion of phaseolin in a baculovirus system. Plant Mol. Biol. 10:475-488.

4. Butters, T. D., and R. C. Hughes. 1981. Isolation and characterization of mosquito cell membrane glycoproteins. Biochim. Biophys. Acta 640:655-671.

5. Butters, T. D., R. C. Hughes, and P. Vischer. 1981. Steps in the biosynthesis of mosquito cell membrane glycoproteins and the effects of tunicamycin. Biochim. Biophys. Acta 640:672-686.

6. Charlton, C. A., and L. E. Volkman. 1986. Effect of tunicamycin on the structural proteins and infectivity of budded Autographa californica nuclear polyhedrosis virus. Virology 154:214-218.

7. Elbein, A. D. 1987. Inhibitors of the biosynthesis and processing of N-linked oligosaccharide chains. Annu. Rev. Biochem. 56: 497-534.

8. Farquhar, M. G. 1985. Progress in unraveling pathways of Golgi traffic. Annu. Rev. Cell Biol. 1:447-488.

9. Gething, M.-J., K. McCammon, and J. Sambrook. 1986. Expression of wild-type and mutant forms of influenza hemagglutinin: the role of folding in intracellular transport. Cell 46:939-950.

10. Greenfield, C., G. Patel, S. Clark, N. Jones, and M. D. Waterfield. 1988. Expression of the human EGF receptor with ligandstimulatable kinase activity in insect cells using a baculovirus vector. EMBO J. 7:139-146.

11. Haas, I. G., and M. Wabl. 1983. Immunoglobulin heavy-chain binding protein. Nature (London) 306:387-389.

12. Hsieh, P., and P. W. Robbins. 1984. Regulation of asparaginelinked oligosaccharide processing. Oligosaccharide processing in Aedes albopictus mosquito cells. J. Biol. Chem. 259:23752382.

13. Kessler, S. W. 1975. Rapid isolation of antigens from cells with a staphylococcal protein A-antibody adsorbent: parameters of the interaction of antibody-antigen complexes with protein A. J. Immunol. 115:1617-1624. 
14. Kornfeld, R., and S. Kornfeld. 1985. Assembly of asparaginelinked oligosaccharides. Annu. Rev. Biochem. 54:631-664.

15. Kreis, T. E., and H. F. Lodish. 1986. Oligomerization is essential for transport of vesicular stomatitis viral glycoprotein to the cell surface. Cell 46:929-937.

16. Kukuruzinska, M. A., M. L. E. Bergh, and B. J. Jackson. 1987. Protein glycosylation in yeast. Annu. Rev. Biochem. 56:915944.

17. Kuroda, K., C. Hauser, R. Rott, H.-D. Klenk, and W. Doerfler. 1986. Expression of the influenza virus haemagglutinin in insect cells by a baculovirus vector. EMBO J. 5:1359-1365.

18. Laemmli, U. K. 1970. Cleavage of structural proteins during the assembly of the head of bacteriophage T4. Nature (London) 227:680-685.

19. Luckow, V. A., and M. D. Summers. 1988. Trends in the development of baculovirus expression vectors. Bio/Technology 6:47-55.

20. Munro, S., and H. R. B. Pelham. 1986. An Hsp70-like protein in the ER: identity with the $78 \mathrm{kd}$ glucose-regulated protein and immunoglobulin heavy chain binding protein. Cell 46:291-300.

21. Nagao, E., N. Takahashi, and H. Chino. 1987. Asparagine-linked oligosaccharides of locust lipophorin. Insect Biochem. 17:531538.

22. Olden, K., B. A. Bernard, M. J. Humphries, T.-K. Yeo, K.-T. Yeo, S. L. White, S. A. Newton, H. C. Bauer, and J. B. Parent. 1985. Function of glycoprotein glycans. Trends Biochem. Sci. 10:78-82.

23. Olden, K., B. A. Bernard, S. L. White, and J. B. Parent. 1982. Function of the carbohydrate moieties of glycoproteins. J. Cell. Biochem. 18:313-335.

24. Pennica, D., W. E. Holmes, W. J. Kohr, R. N. Harkins, G. A. Vehar, C. A. Ward, W. F. Bennett, E. Yelverton, P. H. Seeburg, H. L. Heyneker, D. V. Goeddel, and D. Collen. 1983. Cloning and expression of human tissue-type plasminogen activator cDNA in E. coli. Nature (London) 301:214-221.

25. Pennock, G. D., C. Shoemaker, and L. K. Miller. 1984. Strong and regulated expression of Escherichia coli $\beta$-galactosidase in insect cells with a baculovirus vector. Mol. Cell. Biol. 4:399 406.

26. Pohl, G., H. Jornvall, P. Kok, and P. Wallen. 1986. Porcine tissue plasminogen activator: immunoaffinity purification, structural properties and glycosylation pattern. FEBS Lett. 205:9296.

27. Pohl, G., M. Kallstrom, N. Bergsdorf, P. Wallen, and $\mathbf{H}$. Jornvall. 1984. Tissue plasminogen activator: peptide analyses confirm an indirectly derived amino acid sequence, identify the active site serine residue, establish glycosylation sites, and localize variant differences. Biochemistry 23:3701-3707.

28. Possee, R. D. 1986. Cell-surface expression of influenza virus hemagglutination in insect cells using a baculovirus vector. Virus Res. 5:43-59.

29. Rijken, D. C., and D. Collen. 1981. Purification and characterization of the plasminogen activator secreted by human melanoma cells in culture. J. Biol. Chem. 256:7035-7041.
30. Ryan, R. O., D. R. Anderson, W. G. Grimes, and J. H. Law. 1985. Arylphorin from Manduca sexta: carbohydrate structure and immunological studies. Arch. Biochem. Biophys. 243:115124.

31. Smith, G. E., M. J. Fraser, and M. D. Summers. 1983. Molecular engineering of the Autographa californica nuclear polyhedrosis genome: deletion mutations within the polyhedrin gene. J. Virol. 46:584-593.

32. Smith, G. E., and M. D. Summers. 1978. Analysis of baculovirus genomes with restriction endonucleases. Virology 89:517-527.

33. Smith, G. E., M. D. Summers, and M. J. Fraser. 1983. Production of human beta interferon in insect cells infected with a baculovirus expression vector. Mol. Cell. Biol. 3:2156-2165.

34. Sobel, B. E. 1986. Coronary thrombolysis with tissue-type plasminogen activator (tPA): emerging strategies. J. Am. Coll. Cardiol. 5:1220-1225.

35. Summers, M. D., and G. E. Smith. 1987. A manual of methods for baculovirus vectors and insect cell culture procedures. Tex. Agric. Exp. Stn. Bull. 1555.

36. Takatsuki, A., K. Kohno, and G. Tamura. 1975. Inhibition of biosynthesis of polyisoprenol sugars in chick embryo microsomes by tunicamycin. Agric. Biol. Chem. 39:2089-2091.

37. Tarentino, A. L., C. M. Gomez, and T. H. Plummer, Jr. 1985. Deglycosylation of asparagine-linked glycans by peptide:Nglycosidase F. Biochemistry 24:4665-4671.

38. Tarentino, A. L., and F. Maley. 1974. Purification and properties of an endo- $\beta-\mathrm{N}$-acetylglucosaminidase from Streptomyces griseus. J. Biol. Chem. 249:811-817.

39. Tarentino, A. L., and F. Maley. 1975. A comparison of the substrate specificities of endo- $\beta-\mathrm{N}$-acetylglucosaminidases from Streptomyces griseus and Diplococcus pneumoniae. Biochem. Biophys. Res. Commun. 67:455-462.

40. Towbin, H., T. Staehelin, and J. Gordon. 1979. Electrophoretic transfer of proteins from polyacrylamide gels to nitrocellulose sheets: procedure and some applications. Proc. Natl. Acad. Sci. USA 76:4350-4354.

41. Vaughn, J. L., R. H. Goodwin, G. J. Thompkins, and P. McCawley. 1977. The establishment of two insect cell lines from the insect Spodoptera frugiperda (Leptidoptera:Noctuidae). In Vitro (Rockville) 13:213-217.

42. Wallen, P., N. Bergsdorf, and M. Ranby. 1982. Purification and identification of two structural variants of porcine tissue plasminogen activator by affinity adsorption on fibrin. Biochim. Biophys. Acta 719:318-328.

43. Wallen, P., G. Pohl, N. Bergsdorf, M. Ranby, T. Ny, and H. Jornvall. 1983. Purification and characterization of a melanoma cell plasminogen activator. Eur. J. Biochem. 132:681-686.

44. Wojchowski, D. M., S. H. Orkin, and A. J. Sytkowski. 1987. Active human erythropoietin expressed in insect cells using a baculovirus vector: a role for $\mathrm{N}$-linked oligosaccharide. Biochim. Biophys. Acta 910:224-232.

45. Wojchowski, D. M., P. Parsons, J. H. Nordin, and J. G. Kunkel. 1986. Processing of pro-vitellogenin in insect fat body: a role for high-mannose oligosaccharide. Dev. Biol. 116:422-430. 